\title{
COMPETENCE OF GRADUATES OF HIGHER PROFESSIONAL EDUCATION AS AN OBJECT OF SOCIOLOGICAL REFLECTION
}

Valentina Vladimirovna Fursova Kazan Federal University, Kazan, Russia

Makpal Barkiyayevna Syzdykova Kazan Federal University, Kazan, Russia

Talant Dyusenuli Bimakhanov Kyzylorda State University named after Korkyt Ata

Maria Alievna Makhambetova Kazan Federal University, Kazan, Russia

\section{Citación sugerida:}

Fursova, V.V., Syzdykova, M.B., Dyusenuli Bimakhanov, T. y Makhambetova, M.A. (2019). Competence of graduates of higher professional education as an object of sociological reflection. 3C TIC. Cuadernos de desarrollo aplicados a las TIC. Edición Especial, Octubre 2019, 205-217. doi: https://doi.org/10.17993/3ctic.2019.83-2.206-217

\section{Suggested citation:}

Fursova, V.V., Syzdykova, M.B., Dyusenuli Bimakhanov, T. \& Makhambetova, M.A. (2019). Competence of graduates of higher professional education as an object of sociological reflection. 3C TIC. Cuadernos de desarrollo aplicados a las TIC. Special Issue, October 2019, 205-217. doi: https://doi.org/10.17993/3ctic.2019.83-2.206-217 


\section{ABSTRACT}

The relevance of the chosen research topic lies primarily in the increasing share of young professionals in the workforce and the need to develop, in this regard, measures to address problems related to youth unemployment in Kazakhstan. The authors note that the education system does not always form students' competencies that are in demand on the labor market, as a result of which employers do not want to hire university graduates, prefer workers with experience, which contributes to the growth of unemployment among university graduates. In this regard, the authors conducted an expert survey of the heads of organizations in order to identify their views on the competencies of university graduates needed in the labor market (130 people were interviewed).

Recommendations for improving the education system with the aim of forming competencies important in the modern labor market are offered.

\section{KEYWORDS}

Youth, University Graduates, Competencies, Employer, Competitiveness, Unemployment. 


\section{INTRODUCTION}

Youth unemployment in modern Kazakhstan is due to the fact that young professionals after graduation are looking for work but face the problem that employers do not need them due to the fact that universities do not teach the necessary competencies in demand in the labor market. Well-known British sociologist J. Goldthorpe in the analysis of the labor market introduces the concept of "labor situation" and defines it as a set of social relations in which "a person is involved at work through his position in the division of labor" (Goldthorpe et al., 1987). In this context, young people cannot find a job because of the incompatibility of their competencies with the skills required by employers, and therefore the "work situation" is violated. Market conditions are a "set of material rewards and life chances", as R. Erickson notes (Erikson \& Goldthorpe, 2012, p. 176). As for life chances, they are low among Kazakhstani youth.

Social problems of unemployment among young specialists are studied by Ganskau, Ponomarenko, Geleta, Akulich, Zaslavskaya, Savinova, Borisova, Kuzmin, Maslova, Vidyapin, Zhuravleva. It is sociologists who mainly attracted the attention of the public to employment as a social problem.

The modern labor market in Kazakhstan is characterized by high level of unemployment, late payroll, a gap between the needs of society and prestigious professions, dissatisfaction of employers with the education system, etc. (Shedenova, 2008, p. 518-522). The entry of young people into the labor market is accompanied by considerable difficulties and contradictions. The reason for these problems may be related to the incompetence of young people due to the lack of competencies, since universities do not train practically oriented specialists, and university education lags the needs of employers. Therefore, a significant part of graduates does not find work in their specialty or do not get a job at all, which leads to an increase in unemployment among young people. As a result, the invested finances for their education are not justified. There is also a reluctance of employers to hire graduates without work experience because they believe that they lack practical skills and professional competencies. Therefore, 
the relevance of research is that it is necessary to look for new ways to solve the problem of youth employment in the labor market in accordance with the needs of social development and the current level of economic development. The topic of the research is at the junction of several topical issues of modern society, such as: upbringing and education of young people, comprehensive personal development, scientific management of society.

\section{METHODOLOGY}

In order to assess the opinion of employers about the professional training of specialists by the university and further improve the quality of educational services of the year, a survey was conducted using a method of non-formalized interview among 130 business leaders (April 2019). The survey involved respondents engaged in various forms of professional activity, as well as in various organizational and legal forms of entrepreneurship.

\section{RESULTS AND DISCUSSION}

Employment of university graduates is not only a problem of graduates, but also a problem of these universities. In each university there are two closely related subjects of the market: the first is the educational services market, and the second is the labor market. Therefore, the competitive advantage of an university in the market of educational services is crucial, increasing the guarantee of employment after training and attracting a greater number of applicants. The main task of modern education is to prepare the best specialists, which must be competitive in the labor market. A young specialist should be competent, knowledgeable, versatile, highly qualified specialist who can quickly adapt to the changes that are taking place, able to solve the industrial and innovative situation, is inclined to show self-esteem in society, also able to freely Express their opinion, knowing the high level of knowledge with higher education, have a high level of knowledge, have higher education, possess deep knowledge of the national language, history and culture. 
In modern conditions, universities offer mainly to study for prestigious "market" specialties, since, on the one hand, they are in demand (they are quite popular), on the other hand, they require minimal investments from universities in the form of special equipment, etc. These specialties do not mean that the skills and abilities have been programmed into a specific field, but only store them as providers of quick-reaction capabilities in the market, which is very important at the present time. Applicants consider higher education not as an investment, but as the achievement of social status, which frees the departments of employment of students at universities from the responsibility for the employment of graduates. This conclusion can be made based on how the above departments deal only with collecting certificates of employed graduates. Also, the success of the graduates' professional career is estimated based on the rating system of universities in Europe and America. The latter are interested in a detailed continuation (through research) of their former graduates working career.

The problem of personnel is most relevant for employers. In the field of vocational education, the employer has a demand for the most diversified specialists with higher education. The modern information society requires the training of specialists with a high level of information competence, the ability to quickly navigate in information technology and to apply their knowledge in practice. The significance of information competence is determined by the transition of Kazakhstan society to the stage of informatization (Fursova et al., 2017). This defines new requirements for human resources, including the ability to adapt to the information flow, work with information, perform information loads, work in the information environment. Avraamova and Verpakhovskaya (2006, p.38) in their research found that employers are interested primarily in the following competencies of graduates: decision-making skills and ability to work in a team, activity, initiative and independence, retraining and training for the acquisition of skills and knowledge. At the same time, higher education in the information society is considered a necessary but insufficient condition for employment. 
Personal qualities are also important in the labor market. When hiring a new employee, company managers often take not those who have the appropriate qualifications, but those specialists who differ in their personal qualities. Employees of the personnel agency "Personnel" indicated that, first, employers pay attention to the behavioral aspect of the applicant. It must conform to the corporate culture of the company and have such qualities as: teamwork, flexibility of thinking, search for non-standard solutions and resistance to stress (Official site of the personnel agency "Personnel").

According to the results of the survey conducted by the authors, it turned out that the very first obstacle to the employment of young people today is "lack of work experience", this factor is important in the life of young graduates. The factor "mismatch of the profession with the desired job" is also an important obstacle for young people. It is known that in our society there are differences in the preferences of young people and the chosen specialties. Due to lack of funds, school graduates cannot get the desired profession, many young people are enrolled in specialties for which state grants are allocated. But, they, in turn, do not want to work on the received specialty. "Lack of acquaintances" is the third factor hindering youth employment. It should be noted that in almost all our studies we noticed that factors such as the lack of "acquaintances", the lack of "financial opportunities" always come to the fore. The survey also raised the issue of "lack of knowledge and qualifications." Let's explain this factor by the following example. For example, when a young specialist visits workplace, he is asked several questions during an interview. The employer asks, "Is there any work experience?", "What can you give our company?", "What are you capable of?". This is understandable, it is beneficial for each employer to get a person who knows the job. At the same time, a big problem lies in the fact that applied knowledge in the preparation of future personnel is not sufficiently developed at the university (Employment of Kazakhstani graduates, 2016). Formal practical training of students causes various problems. 
Employers also noted that they are looking for the right workers with the help of numerous resources (through private labor exchanges, through advertising in the media, etc.). However, most employers also use methods such as personal and corporate communications, personal acquaintances, offers and advice from close acquaintances when selecting personnel. The studies of Kazakhstan sociologists also point to this (Indigigyan, 2014, p. 257-262).

Employers also answered questions about their relationship with higher education institutions. For example, we found that only a minimal (about 10\%) number of employers teach copyright lectures. Some noted that they participate in round tables and conferences held at universities. But at the same time there is no close professional interaction between employers and universities. Kazakhstan sociologists also write about this. They note that between universities and employers there are no effective relations in the field of research, commercial or scientific novelty (Maulsharif \& Bolysbaeva, 2017, p. 29-23).

According to the results of a study conducted by Rating.kz research agency with 72 Kazakhstan and international companies, $64.9 \%$ of respondents noted that Kazakhstan universities do not enter any contacts with employers in the process of training specialists. According to employers, many higher educational institutions in our country cannot resist competition from near and far abroad. Managers and specialists of the company confirmed that high quality of specialists are provided by Russian universities (64.9\%) followed by British universities (44.4\%) and American universities (36.1\%) (Ready to work - why not take?, 2017, p. 35$40)$.

Our study showed that due to the lack of practice and special training, employers do not want to hire young people, namely young people aged 16-24. The problem is that graduates of educational institutions do not have work experience, and without experience it is impossible to find a job.

As for educational institutions, in our opinion, it is necessary to make certain changes to the curricula of the university today, that is, to introduce special courses aimed at professional, psychological and ethical training of the future young 
specialist, which will allow to overcome difficulties in the process of employment among young people. Such specialized courses provide young professionals with comprehensive assistance in their employment. It is also necessary to make the transition from one-time actions to continuous cooperation of enterprises and educational institutions. In the conditions of a post-industrial economy, it is very important to develop social partnership in the process of preparing and assessing the quality of education of specialists with higher, secondary and primary education.

\section{SUMMARY}

According to the study, the problems of youth employment, the existing practice of regulating youth employment is not effective enough. In our opinion, the main way to ensure youth employment is to bring the modern education system in line with the requirements of the labor market. For the uniform integration of youth in the labor market in the education system, a competitive basis must be created for each professional level. There are several ways to solve this problem, including the broad holding of information work among young people, aimed at shaping and enhancing the values of work, popularizing working professions. According to the authors, such measures as the formation of entrepreneurial skills among young people, the organization of professional practice in the framework of the University program, improving the quality of professional education, the use of alternative methods of training and retraining of specialists based on the principles of continuous education can improve the situation.

To achieve the relevant qualities (competencies) of graduates, it is necessary to solve the following tasks:

1. Teaching students' practical skills and job search skills, self-employment.

2. Teaching students' self-presentation and interviewing skills. Employers pay attention not only to the diploma, but to what the students have done in an educational process that is interesting and meaningful for their professional 
development. For this, future specialists need to engage in the development of various projects, participate in contests, grants, and conferences, which will allow developing logical thinking, public speaking skills, and scientific discussion skills. In this regard, it is necessary to make certain changes to the curriculum of the university today, that is, if special courses of professional, psychological and ethical training of the future young specialist were introduced, then, in our opinion, several difficulties in young specialists employing could be overcome.

\section{CONCLUSIONS}

Currently, many unemployed young people who have graduated from a higher education institution, with a diploma in their hands do not have the opportunity to find a job on their own. Most of all this difficult problem is faced by newly qualified specialists. Even if they find a job, the employer does not hire them without work experience.

Thus, we can recommend the following measures to universities and employers to solve this problem:

1. Allocate more academic hours for practical classes in enterprises.

2. Increase the time of practical training, based on the student's profile.

3. Improve computer literacy, especially better master MS Excel, MS PowerPoint and all the basic application features.

4. To increase the level of foreign languages knowledge, as a significant part of employers cooperate with foreign companies. 


\section{REFERENCES}

Avraamova, E. M., \& Verpakhovskaya, Yu. B. (2006). Employers and graduates of universities in the labor market: mutual expectations. Sociological Studies, 4, 37-46. Retrieved from https://www.researchgate.net/ publication/296937954_Employers_and_graduate_students_in_the_labor_ market_Mutual_expectations

Employment of Kazakhstani graduates. (2016). Do not buy mater. High school graduate, 3. Retrieved from http://iac.kz/kk/publishing/ kazakstandyk-zhoo-tulekterinin-zhumyska-ornalasuy [In Russian]

Erikson, R., \& Goldthorpe,J. (2012). The Constant Flux: A Study of Class Mobility in Industrial Societies. Oxford: ClarendonPress.

Fursova, V., Shakirova, A., Nikitina, T., Spirchagova, T., \& Syzdykova, M. (2017). Employment of University Graduates Across the Post-soviet Space: Problems and Solutions (The Example of Kazakhstan). Fournal of History Culture and Art Research, 6(4), 470-478. Retrieved from http:/ / kutaksam. karabuk.edu.tr/index.php/ilk/article/view/1115

Goldthorpe, J. H., Llewellyn, G., \& Glive, P. (1987). Social Mobility and Class Structure in Modern Britain ( $2^{\text {nd }}$ ed.). Oxford: Clarendon Press.

Indigigyan, A. A. (2014). Fluctuation of the labor market in the Republic of Kazakhstan: views of employers (based on quality research). "Strategy" Kazakhstan - 2050": social development of society": material of the 5th Congress of Sociologists of Kazakhstan. -Almaty, 257-262.

Maulsharif, M. \& Bolysbaeva, S. (2017). Interaction of higher education institutions with the labor market and the creation of social partnership. Higher School of Kazakhstan, 2, 29-33. [In Russian]

Official site of the personnel agency "Personnel". http://www.personal. barnaul.ru/? Id_page $=15$ \& id_razd $=70$ 
Ready to work - why not take? (2017). University graduate on a duel with the monster of unemployment. Modern education, 4 (88), 35-40.

Shedenova, N. U. (2008). Sociological analysis of the human capital development of young workers in Kazakhstan companies. Civil society and social progress in the twentieth century. Materials of the second congress of sociologists of Turkic-speaking countries and the third congress of sociologists of Kazakhstan, Almaty, 518-522. 